\title{
三菱ヒートパイプ均熱ロールの特長
}

三菱電機株式会社神戸製作所電機製造部電機システム技術課 益 井 博 志

\section{Superior soaking property achieved by integrating the Induction Heating Method and the Heat Pipe}

\author{
Hiroshi Masui \\ Heat control \& mechanical systems engineering section, New energy \& mechanical systems department, \\ KOBE Works, MITSUBISHI Electric Corporation.
}

The Mitsubishi Heat Pipe Type Heating Roll was made possible by combining the induction heating method, by which the roll itself is heated by the induction coil built into the roll, and the heat pipe mounted on the roll part.

Thanks to the soaking effect of the heat pipe, the soaking property on the overall roll surface is largely improved.

\section{1. まえがき}

三菱ヒートパイプ式均熱ロールは，ロール内部に組 み込まれた誘導コイルにより直接ロール自体が発熱す る誘導加熱方式と，ロール内部に設けたヒートパイプ を組み合わせたもので，ヒートパイプの均熱作用によ ってロール表面全域の均熱性を著しく向上させた加熱 ロールであり, 特にラミネーター・カレンダー・コー
ター等をはじめとして幅広く使用さている誘導加熱口 ールである。

\section{2. 三菱ヒートパイプ式均熱ロールの構造と} 原理

\section{1 構 造}

図 1 参照。

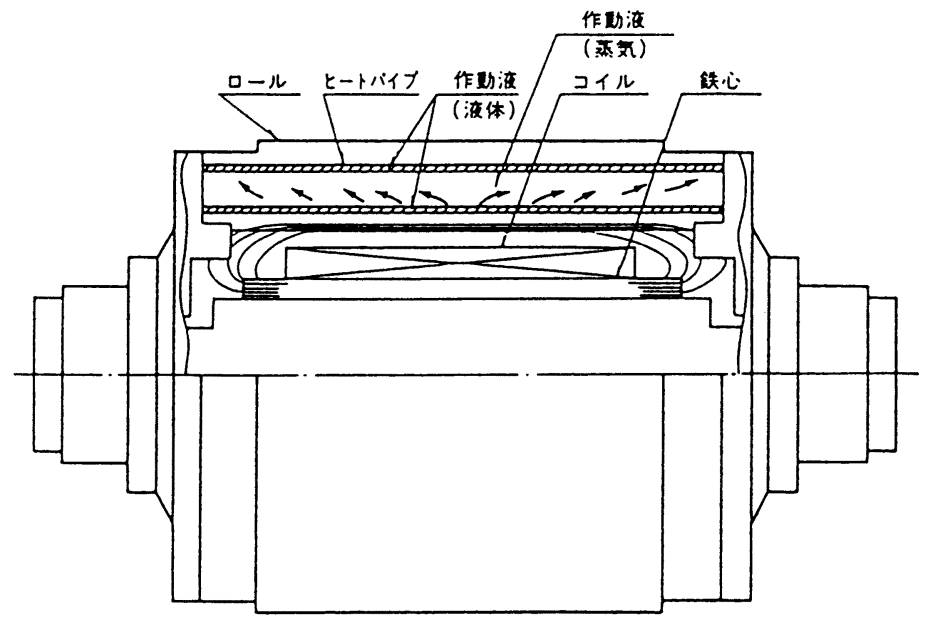

図 1 三菱ヒートパイプ式均熱ロールの構造

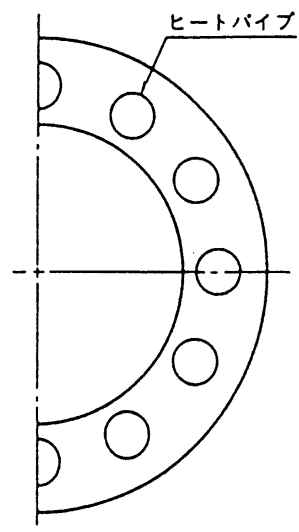

紙パ技協誌 第 49 巻第 2 号 


\section{2 原理}

（1）熱源

加熱用熱源には誘導加熱方式*を採用している。こ の方式はロール自体が発熱するため, 他の加熱源（例 えば，蒸気・高温油等）を採用した方式に比較して効 率並びにレスポンスを含めた温度制御性の面で良好な 加熱が得られ，また付帯設備も軽減される。

*誘導加熱方式：ロール中心部に配置したコイルに 交流電流を流し, 生じた交番磁界をロール本体に 導き，電磁誘導作用によってロール内面に誘起し た電流でロール本体自体を発熱させる加熱方式。

（2）均 熱 性

ロール表面の温度を有効長全域にわたって均一に保 つため，銅の数十倍から数百倍の熱輸送能力のある七 一トパイプをロール本体内の円周上に多数配置してい る。この結果, ロール有効長内における表面の温度分 布を土 $1^{\circ} \mathrm{C}$ 以内に保持することが可能である。

\section{3. ヒートパイプについて}

ヒートパイプとは熱伝導率の極めて高い伝熱管のこ とで，その概念は 1940 年，アメリカ GM 社の R. S. Gaugler 氏により初めて研究され，その後 20 年余り 埋もれたままになっていたが, 1960 年代の航空宇宙 産業の発展とともにヒートパイプの研究開発は急速な 進展をとげ，1967 年の人工衛星への実用化を端緒と して順次民生用，工業用へとその用途を拡大してきて いる。

ヒートパイプは図 2 に示すように, 円筒の容器にウ イックと呼ばれる多孔質材を内張りし，真空減圧後少 量の液体（作動流体）を充填して密封したもので，七 一トパイプの一端を加熱すると, 内部に封入されてい る作動流体は蒸気となり他端へ移動する。他端で冷却 されている作動流体は液体となりウィックを通り蒸発 部へ戻る。これらがパイプ内で絶えず繰り返され, 熱 は一端から他端へと伝えられる。

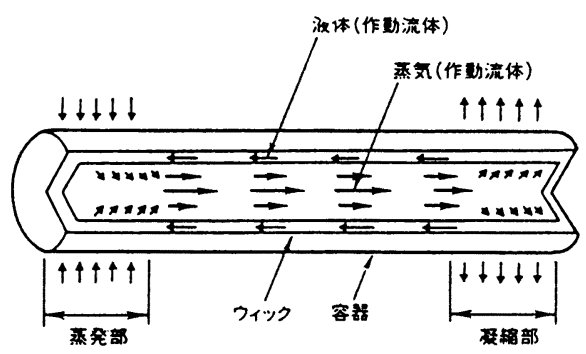

図 2 ヒートパイプの構造と原理

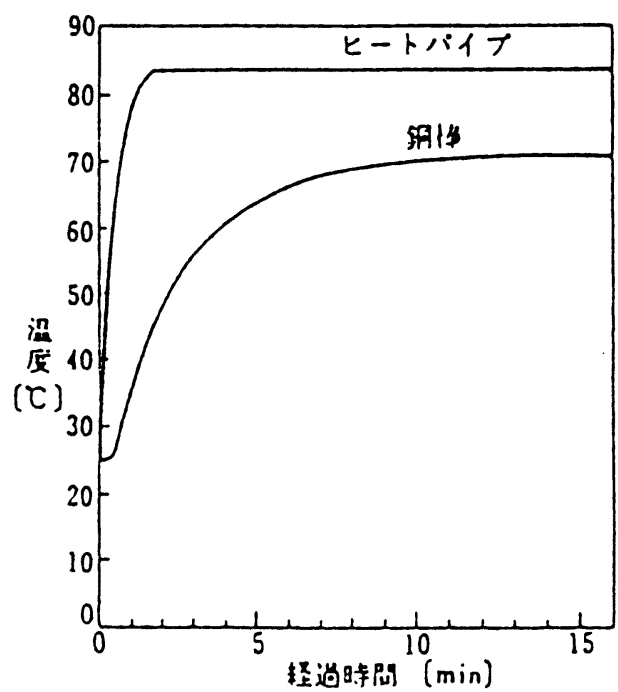

図 3 ヒートパイプと銅棒の伝熱比較

このように，作動流体の相変化（液体 $\rightarrow$ 蒸気）に伴 う潜熱を利用して熱輸送を行うため, 僅かの温度差で 大きな熱をスピーディー且つ効率良く輸送することが できる(図 3 参照)。

ヒートパイプの性能を左右する要因として均熱ロー ルへのヒートパイプ応用時に特に留意しなければなら ない点として

(1)真空度の問題

ヒートパイプ容器内の真空度は高い程性能の良いも のとなる。

(2) ヒートパイプ容器の材料と作動流体の選定の問題 ヒートパイプ容器の材料と作動流体の選定に当たっ てはその組み合わせについて特に留意する必要がある。 たとえば容器の材料として鉄，作動流体として水を組 み合わせた場合，水は鉄と反応するので，この結果と して容器内にがスが発生し容器内の真空度が低下する こととなり, 均熱ロールの経年的性能劣化として表面 化することになる。

当社では長年の研究に裏付けされた成果として特に この点に注意を払っており, 経年的性能劣化の無い七 一トパイプを装着した均熱ロールを提供することが可 能である。

(3)容器内の作動流体の充填量の問題

容器内に充填する作動流体は，多過ぎると熱抵抗と なり性能を充分に発揮することができない。又逆に少 なすぎても液涸れしてしまい同様に性能を発揮しなく なる。

作動流体の適性充填量についても長年に渡って積み 
重ねられてきた当社のヒートパイプに対する研究と実 績が反映され，性能の良い均熱ロールを製作すること が可能となっている。

\section{4. 三菱ヒートパイプ式均熱ロールの特長}

（1）すぐれた均熱性能

ヒートパイプの均熱作用によりロール表面全域で高 い均熱性を有している。ヒートパイプ容器と作動液の 適切な組合せによりヒートパイプ内部の真空度は経年 的に劣化せず，従ってガス抜き作業は必要としない。 図 4 に示すように温度分布が良く，ロール全長に対し て均熱部分が長い（言い替えれば無効長が短くなる） ので, 取り扱う製品の歩留まりが改善される。或いは 機械装置がコンパクトになり機械の設置スペースが改 善される。

特にカレンダーロールの場合, ロール表面の温度差 がロール直径の熱膨張差となって上下のロール間の隙 間変動となる結果, 取り扱う製品の密度・厚み・平滑 性・光沢等に影響を与えることとなるが，このような 問題が改善される。

（2）負荷応答性

ヒートパイプの作用により, 負荷変動に対してすば やくロール表面の均熱性を保つことができる。負荷の 通らないロール表面も負荷を受けるロール表面と温度 を同一にしようとするヒートパイプの働きがあり, 二 ップロールの寿命が改善される。

(3) 省エネルギー性

ロール自体を発熱させているため配管途中での熱放 散等を含む熱損失が少なく, 他の加熱方式にくらべ省 エネルギーが実現される。ロールの温度を直接制御し ているので, 設定温度そのものの精度が改善されると 共に温度制御のレスポンスが早くなり, 設定温度に対 するオーバーシュート或いはアンダーシュートといっ

(c)

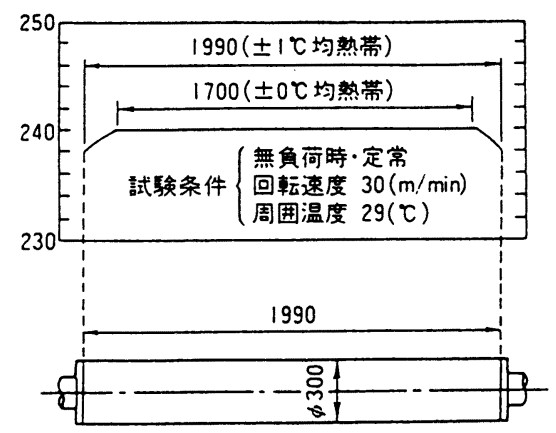

図 4 均熱ロール表面温度分布実測例
た問題も改善される。

（4）操作が容易

電気誘導加熱のため温度制御がしやすく, 使用温度 に合わせて容易に温度設定が可能である。夏場と冬場 との周囲温度の違い等, 周囲温度に影響される度合い が少なくなるので, 上述したレスポンスの改善効果と 併せて操作が容易となる。

特に熟練作業者の長期的確保が困難となっている昨 今, 温度設定を含めて操作の容易なシステムは, 長年 の経験によって温度の設定値を決めていたといったよ うな問題が解決される。

(5) 付帯設備が不要

ロール自体に加熱源を持っているために他に加熱装 置・配管などの付帯設備が不要である。特にロータリ ージョイントが不要となるので, ロータリージョイン 卜を交換する際に生じる液媒の漏れと高温の液媒に対 する火傷等の安全衛生問題に対する解決手段となる。

\section{5. 温度制御方式}

ロール温度はロールに埋め込まれた温度検出センサ 一により検出され, 温度制御盤内部の温度調節器にフ イードバックされる。

温度調節器により, ロール温度とロール温度設定值 を比較し PID 制御により電力量の制御を行う。その ためにロールは常にロール温度設定值に保たれる。ま た, PIDのパラメータはオートチューニング機構に より自動設定されるので，常に最適な制御が行われる。

\section{6. ロール材質とニップ圧}

ロールの材質は一般的には機械構造用炭素鋼を使用 し, 必要に応じてロール表面に硬質クロームメッキ・ テフロンコーティング・セラミックコーティング・ゴ ムライニング・エンボス加工等を施す。

なおカレンダーロール等では, 基本的に硬度と面摩 耗に優れ, 機械強度と勒性に富み過酷な使用に耐える ものでなければならないと共に, 取り扱う製品との相 性といった問題もあり, 必要に応じて鍛鋼ロール或い はその他の特殊な材料を用いる場合もある。

ニップ圧についての現在の業界動向は 60〜 $500 \mathrm{~kg} /$ $\mathrm{cm}$ 程度とみられているが, 当社では一部特殊な用途 として $1,500 \mathrm{~kg} / \mathrm{cm}$ という超高圧ロールも実現して おり, 機械精度も含めて業界の要求に充分応えられる 技術力を有している。

\section{7. ロール加熱の効果とその用途}

加熱・加圧処理することは一般的にアイロン効果と 
称せられており, 纎維結合で表面がざらざらしている ものを適当な温度でアイロンかけをする効果を期待さ れている。

ロールを加温することによる材料への効果は, 取り 扱う材料の種類によってその重要度も異なってくるも のと考えられるが，カレンダーロールでは，

(1)低ニップ圧で必要な材料厚さが得られる

(2)少ないニップ数で平滑度・光沢の改善が図られる

(3)材料強度の低下を抑制出来る，場合によっては材

料強度の向上が図れる

(4)密度等を含み均一な材料が得られる

等の効果により加熱ロールが使用される。

その他，材料を加熱軟化させることにより

(1)フィルム等の熱延伸用, 或いは延伸後の熱固定用

(2)フィルム・金属簿・紙・不織布等のラミネーター, コータ用

(3)印刷・人造皮革・不織布の模様等を含む熱転写の 分野

(4)フィルム・シート等のしわ取り, 歪取りに使用さ れるシーズニング・アニーリング用

等の用途に応用されているが, 最近では乾燥工程ライ ンの設備の長さを短縮するために, 印刷・塗装工程等 への乾燥用として, 或いは一部業界での蒸着用等へと その用途が広がりつつある。

\section{8. 業界の動向}

近年，どの業界においても取り扱う製品のグレード
アップ・操業効率化等に伴うロールの高温化・高圧 化・高速化・高精度化等の動きに対し, 従来の加熱方 式である『蒸気加熱方式』『温水加熱方式』等では加 熱出来る温度そのものに限界があることと, ロール表 面の温度分布精度, 又圧力容器としてのライセンス取 得, ロータリージョイントが必要であること等, 種々 の問題が内在しており，この結果として，

(1)外的条件の影響を受け易いことからロール温度設 定に経験と熟練を要するため, 熟練作業者確保の 問題

(2)ロール表面の温度分布精度が外的条件により变化 を受け易いために定期的にロール表面温度を計測 せざるを得ない等, 取り扱う製品の品質確保上の 問題

(3)ロータリージョイントを交換する際に発生する液 媒の漏れとこれの処理に対する職場環境上の問題, 或いは高温の液媒に対する火傷等安全衛生上の問 題

(4)ボイラー新設に対する環境公害問題への配虑

(5)圧力容器としてのライセンス取得が困難な一部の 国への, 輸出上の制限

等の問題が顕在化しており，これら問題点を解決する 手段の一つとしてヒートパイプ理論を応用した電気誘 導加熱方式の均熱ロールの採用が今後とも加速される ものと考えられる。 